\title{
KARAKTERISTIK BRIKET DARI SEKAM PADI DAN KETAMAN KAYU BERPEREKAT DAUN JAMBU METE
}

\author{
Widya Gema Bestari, Mutiara Mendopa, Rosdanelli Hasibuan \\ Departemen Teknik Kimia, Fakultas Teknik, Universitas Sumatera Utara \\ Jl.Almamater Kampus USU Medan 20155, Indonesia \\ Email: wiwied_gb@yahoo.com
}

\begin{abstract}
Abstrak
Briket adalah suatu teknologi pemadatan biomassa sebagai sumber energi alternatif dengan atau tanpa perekat dengan bentuk dan ukuran yang berbeda. Penelitian ini bertujuan untuk menganalisis proses pengarangan, tekanan pengempaan, dan konsentrasi perekat yang paling baik terhadap kualitas briket. Pada penelitian ini bahan baku yang digunakan adalah sekam padi dan ketaman kayu yang diarangkan dengan dua proses berbeda, yaitu proses pengarangan 1 dan proses pengarangan 2. Proses pengarangan 1 dilakukan dengan mengarangkan masing-masing bahan baku kemudian dicampur sedangkan proses pengarangan 2 dilakukan dengan mencampur kedua bahan baku kemudian diarangkan. Bahan baku kemudian dicampur dengan perekat daun jambu mete dengan konsentrasi 10\%, 12,5\%, 15\%, dan 20\% serta dikempa dengan tekanan $85 \mathrm{~kg} / \mathrm{cm}^{2}$ dan $105 \mathrm{~kg} / \mathrm{cm}^{2}$. Briket yang paling baik yaitu campuran sekam padi dan ketaman kayu yang dikarbonisasi pada proses pengarangan 1 dengan $15 \%$ perekat dan dikempa dengan tekanan $85 \mathrm{~kg} / \mathrm{cm}^{2}$ dengan nilai kalor 3045,8271 kal/g.
\end{abstract}

Kata kunci : briket, daun jambu mete, ketaman kayu, sekam padi

\begin{abstract}
Briquettes are biomass compaction technology as alternative energy sources with or without binder in different shape and size. The research is aimed to analyze the best carbonization process, compaction pressure and binder concentration for quality of briquettes. In this resarch, rice husk and wood shaving are used as raw materials carbonized at different process, named by carbonization process 1 and other carbonization process 2. Carbonization process 1 was done by carbonized each raw material and then mixed while carbonization process 2 was done by mixed raw materials then carbonized. Raw materials were blended with cashew nut leaves binder at concentration 10\%, 12,5\%, 15\%, and 20\% and then compacted at pressure $85 \mathrm{~kg} / \mathrm{cm}^{2}$ and 105 $\mathrm{kg} / \mathrm{cm}^{2}$. The best briquette was briquette that rice husk and wood shaving were carbonized by carbonization process 1 blended with $15 \%$ binder and compacted at $85 \mathrm{~kg} / \mathrm{cm}^{2}$ and had calorific value 2045,8271 cal/g.
\end{abstract}

Keywords: briquettes, cashew nut leaves, wood shaving, rice husk

\section{Pendahuluan}

Energi tidak dapat dipisahkan dari kehidupan manusia. Manusia membutuhkan energi untuk menunjang kehidupan sehari-hari. Bahkan, permintaan terhadap energi di dunia semakin meningkat setiap tahunnya, yakni sekitar 1,6\% [21, 4].

Pada Gambar 1 terlihat bahwa konsumsi energi di Indonesia semakin meningkat setiap tahun hingga mencapai 1.116,1 juta SBM (Setara Barel Minyak)pada tahun 2011. Konsumsi energi masih didominasi oleh BBM (32,7\%), diikuti oleh biomassa $(25,1 \%)$, dan batubara $(1,3 \%)$ [18].

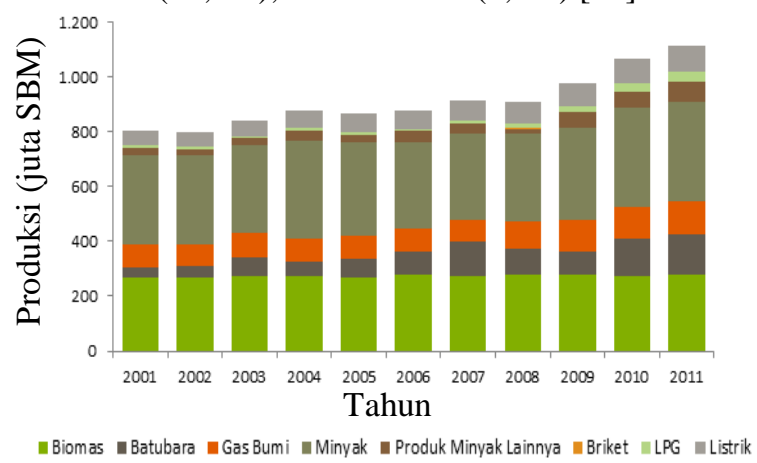

Gambar 1. Konsumsi Energi di Indonesia
Minyak merupakan sumber energi tak terbarukan yang populer sebagai sumber utama bahan bakar. Jadi tidak dapat disangkal bahwa minyak suatu saat akan habis akibat pemakaian secara terus menerus [10].Oleh karena persediaan minyak yang terbatas dan semakin menipis, maka dicarilah sumbersumber energi terbarukan sebagai alternatif menghadapi krisis minyak.

\section{Teori}

Biomassa adalah salah satu sumber energi terbarukan yang paling umum dan mudah didapat dan merupakan peluang besar sebagai bahan baku untuk bioenergi [11]. Beberapa sumber utama biomassa di Indonesia dapat diperoleh dari limbah kelapa sawit, tebu, kelapa, hasil pengolahan limbah kayu dan limbah pertanian [19].

Sekam padi dan limbah kayu cukup banyak dihasilkan di Indonesia seperti yang terlihat pada tabel 1 dan tabel 2. Di Sumatera Utara saja limbah kayu gergajian cukup banyak dan ternyata hanya sebagian saja (35-49\%) limbah kayu yang dieksploitasi dan belum dimanfaatkan secara maksimal. Limbah kayu yang dihasilkan antara lain 
serbuk gergaji, lembaran kayu, kulit kayu dan ketaman kayu

Tabel 1. Data Produksi Padi dan Sekam Padi pada Tahun 2007-2010 [7]

\begin{tabular}{|c|c|c|}
\hline \multirow{2}{*}{ Tahun } & \multicolumn{2}{|c|}{ Produksi (juta ton) } \\
\cline { 2 - 3 } & Padi & Sekam Padi \\
\hline 2005 & 54 & 10,8 \\
\hline 2006 & 54,45 & 10,89 \\
\hline 2007 & 57,15 & 11,43 \\
\hline 2008 & 60,33 & 12,07 \\
\hline 2009 & 64,40 & 12,88 \\
\hline 2010 & 66,41 & 13,28 \\
\hline
\end{tabular}

Tabel 2. Perkembangan Produksi Gergajian di Sumatera Utara [5]

\begin{tabular}{|c|c|c|}
\hline Tahun & $\begin{array}{c}\text { Kayu } \\
\text { Gergajian } \\
\left(\mathbf{m}^{\mathbf{3}}\right)\end{array}$ & $\begin{array}{c}\text { Limbah Kayu } \\
\text { Gergajian, 50\% } \\
\left(\mathbf{m}^{\mathbf{3}} \mathbf{)}\right.\end{array}$ \\
\hline 2002 & 37.432 & 18.716 \\
\hline 2003 & 7.557 & $3.778,5$ \\
\hline 2004 & 19.915 & $9.957,5$ \\
\hline 2005 & 51.368 & 25.684 \\
\hline 2006 & 66.616 & 33.308 \\
\hline
\end{tabular}

Ada beberapa keuntungan dari produksi dan penggunaan briket biomassa, yaitu:

1. Menyediakan sumber bahan bakar murah untuk keperluan rumah tangga, yang terjangkau oleh semua penduduk

2. Menyediakan sarana yang baik dalam mengkonversi limbah pertanian menjadi benda yang memiliki nilai ekonomi.

3. Membantu melestarikan beberapa sumber daya alam karena merupakan alternatif yang tepat. Oleh karena itu, hal ini akan berguna untuk mengurangi jumlah minyak dan gas yang biasanya digunakan untuk menghasilkan energi bagi keperluan rumah tangga.

4. Menciptakan lapangan kerja bagi orang-orang karena akan dibutuhkan operator untuk mengoperasikan mesin briket, mendistribusikan bahan baku dan menjual briket yang dihasilkan.

5. Produk yang dihasilkan mudah diangkut dan disimpan

6. Proses ini membantu dalam memecahkan masalah penumpukan limbah biomassa

7. Bahan bakar yang dihasilkan seragam dalam ukuran dan kualitas

8. Membantu mengunagi kayu bakar dan penggundulan hutan

9. Briket yang dihasilkan tidak mengandung sulfur

10. Memiliki kualitas yang konsisten dan memiliki efisiensi yang sempurna $[9,12,16]$.

Perekat digunakan untuk mempererat briket [3]. Perekat tersebut dapat mempengaruhi kualitas briket yang dihasilkan seperti sifat termal dan pembakarannya tergantung dari jenis perekat, jumlah perekat dan jumlah air yang digunakan. Daun jambu mete mengandung tannin dengan kadar 4,15\% [20]. Tannin adalah gabungan senyawa fenolat dengan berat molekul 500-3000 [15]. Tannin menyebabkan daun jambu mete bersifat adhesif karena memiliki sifat gelatin [14]. Gelatin merupakan polimer yang bisa bersifat sebagai gelling agent (bahan pembuat gel) dan bersifat mengikat.

\section{Metodologi Penelitian}

Bahan baku yang digunakan dalam penelitian ini adalah sekam padi dan ketaman kayu menggunaan perekat daun jambu mete. Peralatan yang digunakan yaitu timbangan, furnace, desikator, mortar, ayakan, alat press, dan oven. Percobaan dilakukan dengan variasi konsentrasi perekat $10 \%, 12,5 \%, 15 \%$, dan $20 \%$ dan variasi tekanan pengempaan (TP) $85 \mathrm{~kg} / \mathrm{cm}^{2}$ dan 105 $\mathrm{kg} / \mathrm{cm}^{2}$. Selain itu variasi proses pengarangan $(\mathrm{PP})$ juga dilakukan yaitu terbagi atas proses pengarangan 1 (PP1) dan proses pengarangan 2 (PP2). Proses pengarangan 1 yaitu masing-masing bahan baku dengan perbandingan 1:1 diarangkan pada dua cawan yang berbeda kemudian dicampur. Proses pengarangan 2 yaitu kedua bahan baku dicampur dengan perbandingan 1:1 pada cawan yang sama kemudian diarangkan.

Bahan baku yang telah diarangkan dan dicampur dengan perekat kemudian dikempa dengan alat press. Briket tersebut kemudian dianalisa meliputi analisa kadar air, kadar senyawa volatil, kadar abu, kandungan fixed carbon, dan nilai kalor.

\section{Hasil}

Penelitian ini bertujuan untuk mengetahui kualitas briket agar dapat dijadikan sebagai sumber bahan bakar alternatif.

\section{A. Pengaruh Konsentrasi Perekat, Tekanan Pengempaan dan Proses Pengarangan terhadap Kadar Air Briket}

Gambar 2 memperlihatkan kadar air briket pada berbagai konsentrasi perekat, tekanan pengempaan dan proses pengarangan. Kadar air tertinggi mencapai $13 \%$ sedangakan yang terendah adalah 6\%. Rata-rata kadar air mengalami kenaikan seiring dengan penambahan konsentrasi perekat dan tekanan pengempaan. Daun jambu mete sendiri memiliki kandungan air yang cukup besar yaitu $63,83 \%$ [20]. Hal ini menyebabkan semakin banyak konsentrasi perekat maka kadar air semakin banyak pula. Briket dikeringkan di dalam oven pada suhu $105^{\circ} \mathrm{C}$ selama 1 jam. Sehingga pada waktu pengeringan yang sama, briket yang memiliki kadar air lebih banyak membutuhkan waktu yang lama untuk mencapai berat konstan [17].

Briket yang dikempa dengan tekanan $85 \mathrm{~kg} / \mathrm{cm}^{2}$ lebih longgar daripada briket yang dikempa dengan 
tekanan $105 \mathrm{~kg} / \mathrm{cm}^{2}$ yang mengakibatkan panas dapat masuk ke sela-sela briket sehingga luas bidang permukaan yang terkena panas lebih banyak. Semakin luas bidang permukaan maka semakin luas bidang kontak pada proses pengeringan sehingga semakin singkat waktu yang diperlukan untuk mengeringkan suatu bahan.

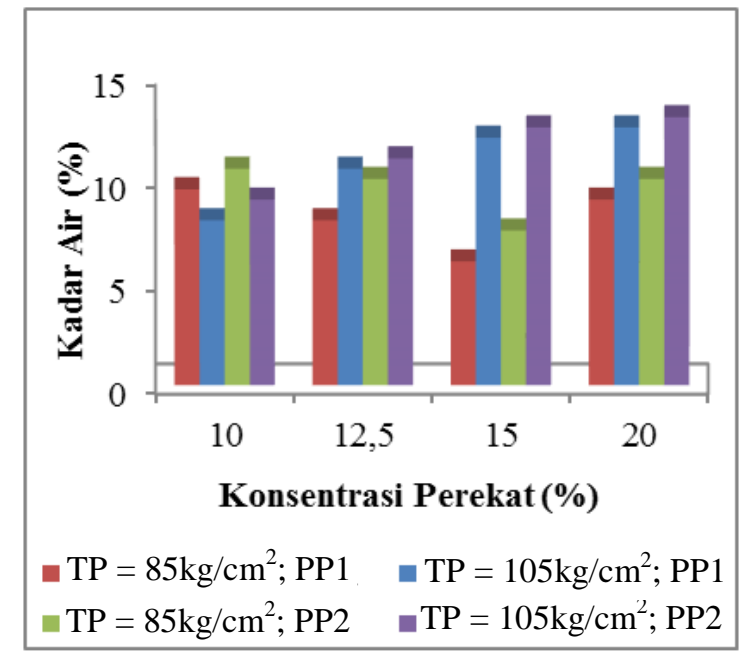

Gambar 2. Kadar Air Briket pada Berbagai Konsentrasi, Tekanan dan Proses Pengarangan

Selain itu, bahan baku yang diarangkan dengan proses pengarangan 2 memiliki kadar air yang lebih tinggi daripada bahan baku yang diarangkan dengan proses pengarangan 1. Pada proses pengarangan 2, salah satu bahan baku mungkin memicu bahan baku lain agar terkarbonisasi lebih cepat sehingga menyebabkan produk dari proses pengarangan terbentuk lebih banyak. Hal ini sesuai dengan reaksi berikut [22]:

$\mathrm{C}_{21} \mathrm{H}_{32} \mathrm{O}_{14} \longrightarrow \mathrm{C}_{7} \mathrm{H}_{4} \mathrm{O}+9 \mathrm{CO}+5 \mathrm{CH}_{4}+4 \mathrm{H}_{2} \mathrm{O}$

B. Pengaruh Konsentrasi Perekat, Tekanan Pengempaan dan Proses Pengarangan terhadap Kadar Senyawa Volatil Briket

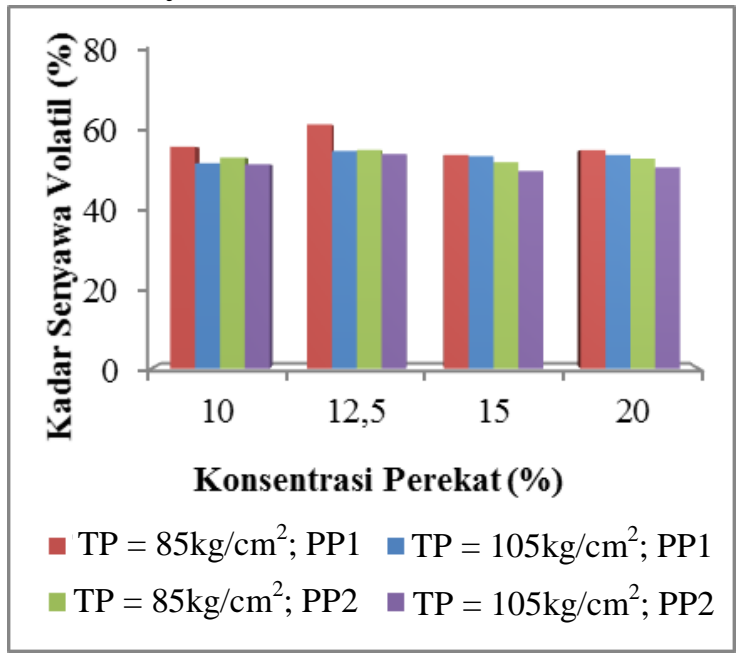

Gambar 3. Kadar Senyawa Volatil Briket pada Berbagai Konsentrasi, Tekanan dan Proses Pengarangan
Gambar 3 memperlihatkan kadar senyawa volatil briket pada berbagai konsentrasi perekat, tekanan pengempaan dan proses pengarangan. Kadar senyawa volatil cukup tinggi dengan kadar senaywa volatil terendah adalah $50,575 \%$ sedangkan kadar volatil tertinggi adalah $61,413 \%$. Daun jambu mete sendiri mengandung asam anakardat, beberapa senyawa volatil dan flavonoid [6]. Asam anakardat, senyawa alkohol dan flavonoid pada daun jambu mete bersifat mudah menguap.

Kadar senyawa volatil dalam biomassa akan membuat biomassa tersebut sangat reaktif dan membuat pembakaran menjadi lebih cepat [11]. Kadar senyawa volatil adalah zat yang dapat menguap sebagai hasil dekomposisi senyawasenyawa yang masih terdapat di dalam arang selain air [5].

\section{Pengaruh Konsentrasi Perekat, Tekanan Pengempaan dan Proses Pengarangan terhadap Kadar Abu Briket}

Gambar 4 menunjukkan kadar abu briket terhadap berbagai konsentrasi perekat, tekanan pengempaan dan proses pengarangan. Semakin banyak konsentrasi perekat dan semakin tinggi tekanan pengempaan tekanan maka kadar abu semakin tinggi.

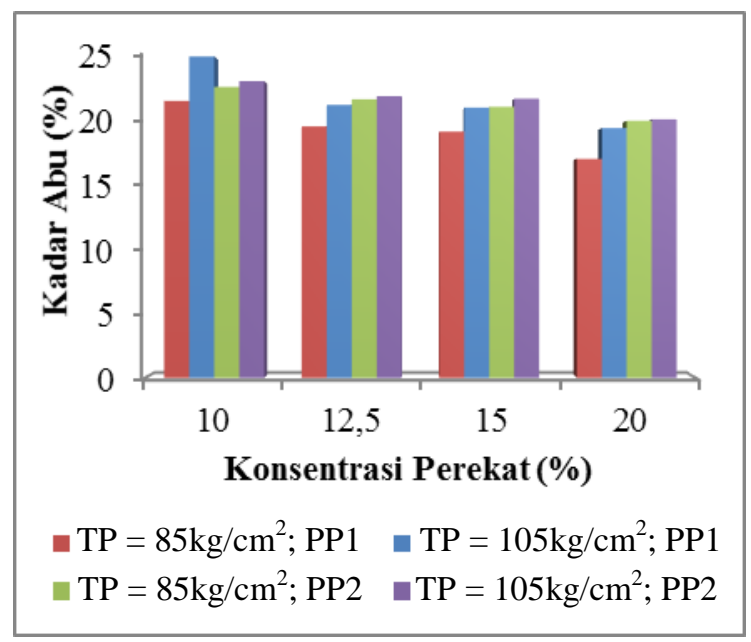

Gambar 4. Kadar Abu Briket pada Berbagai Konsentrasi, Tekanan dan Proses Pengarangan

Kadar abu briket tertinggi mencapai angka 25\% sedangkan kadar abu terendah adalah 17,033\%. Kadar abu daun jambu mete $1,54 \%$ [20] dan kadar abu sekam padi berkisar 18,20-23,40\% [13]. Hal ini menunjukkan bahwa kadar abu perekat lebih rendah dibanding kadar abu bahan dasar sehingga penambahan jumlah konsentrasi perekat akan memicu turunnya kada abu briket.

Proses pengarangan 2 rata-rata meningkatkan kadar abu dibandingkan bahan baku yang diarangkan dengan proses pengarangan 1. Proses pengarangan 2 memungkinkan bahan baku yang 
lebih dulu terkarbonisasi memicu bahan baku lainnya. Akibatnya bahan baku yang waktu mulai karbonisasi lebih lama akan terkarbonisasi lebih awal dan lebih lama daripada normalnya sehingga memungkinkan proses karbonisasi mencapai maksimal sebelum 2 jam dan mulai menjadi abu.

\section{Pengaruh Konsentrasi Perekat, Tekanan Pengempaan dan Proses Pengarangan terhadap Kandungan Fixed Carbon Briket \\ Gambar 5 menunjukkan kandungan fixed} carbon briket pada berbagai konsentrasi perekat, tekanan pengempaan dan proses pengarangan. Kandungan fixed carbon tertinggi adalah 21,128\% sedangkan kandungan fixed carbon terendah adalah $11,022 \%$.

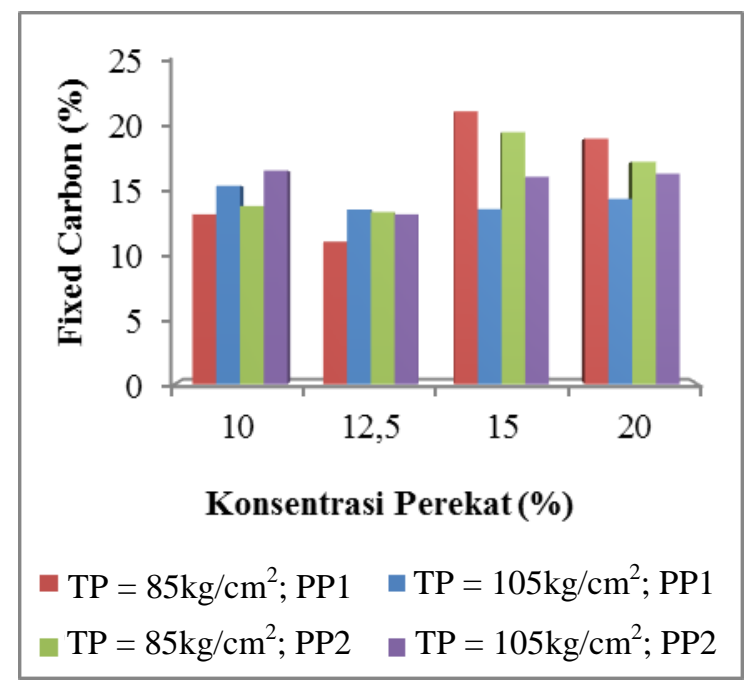

Gambar 5. Kandungan Fixed Carbon Briket pada Berbagai Konsentrasi, Tekanan dan Proses Pengarangan

Konsentrasi perekat, tekanan pengempaan, dan proses pengarangan mempengaruhi kadar air, kadar senyawa volatil dan kadar abu briket. Setelah ketiga hal tersebut diketahui, kandungan fixed carbon dapa dihitung. Kandungan fixed carbon dapat dihitung sesuai dengan persamaan (1) berikut [2]:

Fixed Carbon $=100 \%-(\mathrm{PAC}+\mathrm{PMC}+\mathrm{PVM}) \ldots . .(1)$

Dimana:

$\mathrm{PAC}=$ Percentage of Ash Content

PMC $=$ Percentage of Moisture Content

$\mathrm{PVM}=$ Percentage of Volatile Matter

Fixed carbon adalah fraksi karbon yang terdapat di dalam arang selain fraksi air, senyawa volatil, dan abu. Kandungan fixed carbon mempengaruhi nilai kalor sebuah briket. Semakin tinggi kandungan fixed carbon maka semakin tinggi pula nilai kalor sebuah briket [5]. Oleh karena itu, briket diharapkan memiliki kandungan fixed carbon yang tinggi.
E. Pengaruh Konsentrasi Perekat, Tekanan Pengempaan dan Proses Pengarangan terhadap Nilai Kalor Briket

Gambar 6 memperlihatkan nilai kalor briket pada berbagai konsentrasi perekat, tekanan penegmpaan, dan proses pengarangan.

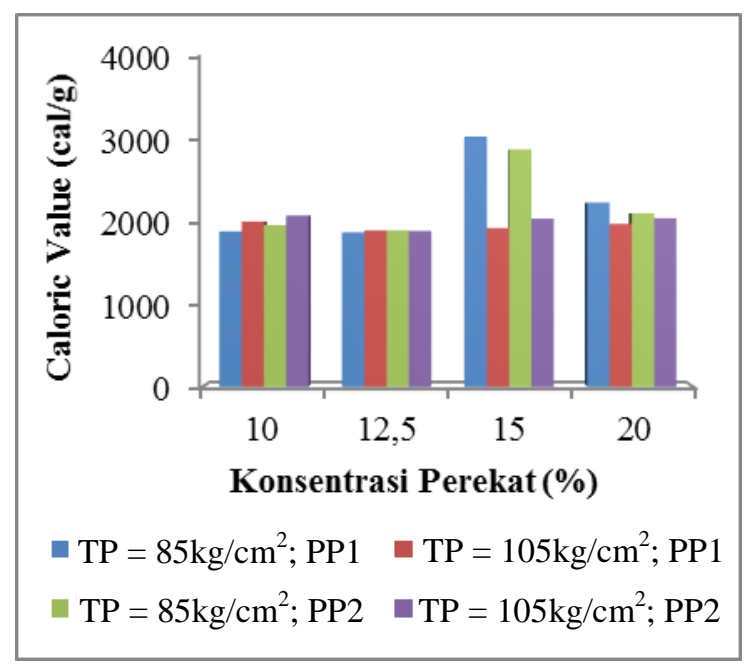

Gambar 6. Nilai Kalor Briket pada Berbagai Konsentrasi, Tekanan dan Proses Pengarangan

Nilai kalor briket tertinggi yaitu 3045, 8271 $\mathrm{kal} / \mathrm{g}$ sedangkan nilai kalor briket terendah adalah $1877,138 \mathrm{kal} / \mathrm{g}$. Nilai kalor briket merupakan indikasi energi yang tersimpan dalam briket untuk digunakan sebagai bahan bakar [11]. Semakin tinggi nilai kalor, maka semakin tinggi pula energi yang tersimpan di dalamnya.

\section{F. Kualitas Briket}

Briket diharapkan memiliki sifat fisik antara lain tidak meninggalkan warna hitam jika dipegang, tidak berjamur, kuat, dan saling merekat satu sama lain agar tidak mudah hancur $[1,8]$.

Pada penelitian ini, sifat fisik briket tidak memenuhi standar karena briket dengan perekat daun jambu mete tidak menghasilkan briket yang cukup merekat sehingga mudah hancur dan tidak kuat. Pada saat briket akan dicetak dan dikeringkan di oven, beberapa briket hancur ketika disentuh karena sangat lunak. Ketika dijatuhkan dari ketinggian \pm 1 meter, briket hancur seketika. Baik briket yang dikempa dengan tekanan pengempaan $85 \mathrm{~kg} / \mathrm{cm}^{2}$ maupun $105 \mathrm{~kg} / \mathrm{cm}^{2}$, keduanya langsung hancur. Daun jambu mete mengandung tanin yang bersifat adhesif sehingga diyakini mampu menjadi perekat dalam pembuatan briket. Namun, berdasarkan hasil yang diperoleh perekat daun jambu mete tidak berfungsi sebagai perekat yang baik. Hal ini karena kandungan tanin dalam daun jambu mete yang tidak terlalu banyak yaitu sekitar $4,15 \%$ [20]. Selain itu, perlu diketahui bahwa dalam pembuatan daun jambu mete sebagai perekat, terlebih dahulu daun jambu mete dicacah 
kecil-kecil dan dihaluskan bersama dengan air agar menjadi larutan. Jadi, dalam larutan perekat tersebut, konsentrasi tanin semakin sedikit karena daun jambu mete sudah dicampur dengan air. Tannin juga bersifat mudah menguap.

\section{Kesimpulan}

1. Daun jambu mete tidak dapat digunakan sebagai perekat dalam pembuatan briket karena briket yang dihasilkan bersifat lunak dan mudah hancur

2. Briket yang paling baik adalah briket yang memiliki nilai kalor paling tinggi yaitu briket yang dikarbonisasi dengan metode pengarangan 1 , dicampur dengan perekat $15 \%$ dan dikempa dengan tekanan $85 \mathrm{~kg} / \mathrm{cm}^{2}$ dengan nilai kalor $3045,8271 \mathrm{kal} / \mathrm{g}$.

3. Nilai kalor briket yang dihasilkan masih berbeda dari standar briket Indonesia yaitu 5000 $\mathrm{kal} / \mathrm{g}$.

\section{Daftar Pustaka}

[1] A. M. M. Urgel, Production of Homemade Biomass Briquettes from Dried Syzygium samarangense (Makopa) Leaves, APEC Youth Scientist Journal, 6, 2, (2014) 135-144.

[2] B. Lonia and R.K. Bansal, An Experimental Approach for Studying the Fuel Chareacteristics of Agricultural Waste Based Charcoal A Case Study, IJMIT, ISSN: 22785612, 5, 3, (2013) 248-257.

[3] Ch. A. I. Raju, K. Ramya Jyothi, M. Satya and U. Praveena, Studies on Development of Fuel Briquettes for Household and Industrial Purpose, IJRET, ISSN: 2319-1163, 3, 2, (2014) 54-63.

[4] D. Behboudi, H. Panahi and S. Moosavi, An Investigation of the Contribution of Renewable and Non-Renewable Energy Consumption to Economic Growth in OIC Countries, IJEMA, 21, 2, (2013) 45-57.

[5] D. S. Wijayanti, Karakteristik Briket Arang dari Serbuk Gergaji dengan Penambahan Arang Cangkang Kelapa Sawit, Thesis, Universitas Sumatera Utara, Indonesia, 2009.

[6] E. U. Putri, Uji Penghambatan Aktivitas $\alpha$ Glukosidase Fraksi dari Ekstrak Metanol Daun Jambu Mete (Anacardium occidentale Linn.) dan Penapisan Fitokimia dari Fraksi Paling Aktif, Thesis, Universitas Indonesia, Indonesia, 2012.

[7] F. P. Utami, Sintesis dan Karakterisasi Zeolit A4 dari Abu Sekam Padi sebagai Penyerap Logam Berat Timbal (II) dan Tembaga (II), Thesis, Universitas Negeri Medan, Indonesia, 2013.

[8] H. A. Lubis, Uji Variasi Komposisi Bahan Pembuat Briket Kotoran Sapi dan Limbah Pertanian, Thesis, Universitas Sumatera Utara, Indonesia, 2011.
[9] I. N. Olivia, Comparative Analysis of Coal Briquette Blends with Groundnut Shell and Maize Cob, Thesis, Nnamdi Azikiwe University, Anambra State, 2010.

[10] J. Friedrichs, Global Energy Crunch: How Different Parts of the World Would React to a Peak Oil Scenario, IJEP, 38, 8, (2010) 4564569

[11] J. O. Akowuah, F. Kemausuor and S. J. Mitchual, Physico-Chemical Characteristics and Market Potential of Sawdust Charcoal Briquette, IJEEE, 3, 20, (2012) 1-6.

[12] K. A. Pakhare and R.N.Baxi, Failure Analysis of Taper Die of Biomass Briquetting Machine: A Review, IJESS, ISSN: 2249-9482, 2, 1, (2012) 39-50.

[13] K. G. Mansaray and A. E. Ghaly, Physical and Thermochemical Properties of Rice Husk, Energy Sources Article, 19, 9, (2007) 9891004.

[14] L. D. Heruwati, Pengaruh Variasi Tekanan pada Pembuatan Briket Arang Tempurung Kelapa dengan Perekat Daun Jambu Mete Muda (Anacardium occidentale L.) terhadap Nilai Kalor yang Dihasilkan, Thesis, Universitas Muhammadiyah Jakarta, Indonesia, 2009.

[15] M. Mekhanzie, Pengaruh Berbagai Konsentrasi Ekstrak Daun Jambu Mete Sebagai Denture Cleanser terhadap Pertumbuhan Candida albicans dengan Waktu Perendaman 15 Menit, Thesis, Universitas Jember, Indonesia, 2012.

[16] Maninder, R. S. Kathuaria and S. Grover, Using Agricultural Residues as a Biomass Briquetting: An Alternative Source of Energy, IOSRJEEE, ISSN: 2278-1676, 1, 5, (2012) 11-15.

[17] N. M. Chinenye, A. S. Ogunlowo and O. J. Olukunle, Cocoa Bean (Theobroma cacao L.) Drying Kinetics, CHILEANJAR, 70, 4, (2010), 633-639.

[18] Pusat Data dan Informasi Energi dan Sumber Daya Mineral, Kajian Indonseia Energy Outlook, Kementrian Energi dan Sumber Daya Mineral, 2012.

[19] R. Balaka, A. Rachman and Ld Muh. G. Jaya, Mitigating Climate Change through the Development of Clean Renewable Energy in Southeast Sulawesi, a Developing Region in Indonesia, IJEIC, 4, 4, (2013) 33-42.

[20] S. Prasetyawati, Komposisi Protein Kokon Cricula trifenestrata Helf. dan Kadar Protein, Air, Abu, Flavonoid, Tanin Daun Jambu Mete, Thesis, UIN Sunan Kalijaga Yogyakarta, Indonesia, 2012.

[21] S. Ozturk, A. Sozdemir and O. Ulger, The Real Crisis Waiting for the World : Oil Problem and Energy Security, IJEEP, ISSN:2146-4553, 3, (2013) 74-79. 
Jurnal Teknik Kimia USU, Vol. 5, No. 2 (Juni 2016)

[22] W. N. R. W. Isahak, M. W. M. Hisham and M. A. Yarmo, Highly Porous Carbon Materials from Biomass by Chemical and Carbonization Method: A Comparison Study, Journal of Chemistry, 2013. 